\title{
DESAIN PEMBELAJARAN KITAB AT-TIBYAN DENGAN MODEL ASSURE DI PESANTREN TAHFIDZ MASKANUL HUFFADZ
}

\author{
Ayu Lestari \\ Pondok Pesantren Tahfidz Maskanul Huffadz, Tangerang Selatan, Banten \\ hma.lestari@gmail.com
}

\begin{abstract}
The study design for the book At-Tibyan is based on the ASSURE model. This learning design consists of six stages of design, starting from analyzing the students to evaluating the results of the learning. The results of the design are (a) learning syllabus in 1 semester, (b) learning materials in the form of PPT and educational videos that support each learning chapter under the learning objectives of the At-Tibyan book, (c) guidelines for assessing student success during the learning program.
\end{abstract}

Keywords: Instructional design; ASSURE model; the book of At-Tibyan; Morals.

\section{ABSTRAK}

Rancangan pembelajaran kitab At-Tibyan ini disusun berdasarkan model ASSURE. Rancangan pembelajaran ini terdiri dari enam tahapan perancangan, dimulai dari melakukan analisis terhadap para santri sampai mengevaluasi hasil dari pembelajaran. Hasil rancangan berupa (a) silabus pembelajaran dalam satu semester, (b) bahan pembelajaran dalam bentuk power point dan video edukatif yang menunjang setiap bab pembelajaran sesuai dengan tujuan pembelajaran kitab AtTibyan, dan (c) pedoman penilaian keberhasilan peserta didik selama program belajar berlangsung.

Kata Kunci: Desain pembelajaran; model ASSURE; kitab At-Tibyan; Akhlak.

\section{PENDAHULUAN}

Fenomena menghafalkan Al-Qur'an saat ini sudah sangat menjamur di manamana. Kegiatan menghafal Al-Qur'an sudah bukan lagi menjadi aktivitas yang bisa dilakukan oleh anak pesantren saja, namun berbagai kalangan di luar lingkungan pesantren pun dapat menghafalkan AlQur'an. Fenomena ini dikhawatirkan dapat mengurangi nilai dari menghafalkan AlQur'an itu sendiri. Khawatir proses menghafal Al-Qur'an hanya menjadi trend belaka tanpa ada efek signifikan dalam proses perbaikan akhlak. Dalam suatu riwayat Hadits dikatakan bahwa akhlak Rasulullah adalah Al-Qur'an. Ketika Ibunda Aisyah radhiyallahu anhā ditanya mengenai akhlak Rasulullah shallallāhu ‘alaihi wa sallam, beliau menjawab: “Akhlak Rasulullah adalah Al-Qur'an” (HR Ahmad).
Merujuk kepada Hadits ini, maka ketika seseorang belajar atau mengkaji isi AlQur'an, maka sesungguhnya juga sedang mempelajari penerapan akhlak. Inilah yang menyebabkan timbul pemahaman bahwa ketika seseorang sedang belajar Al-Qur'an atau bahkan sedang menghafal ayat-demi ayat Al-Qur'an, seharusnya berbanding lurus dengan perbaikan penerapan akhlak seseorang tersebut. Namun dalam realitasnya sering ditemukan bahwa ada orang yang sedang menghafal Al-Qur'an, namun akhlaknya masih belum mencerminkan apa yang terkandung di dalam Al-Qur'an.

Memperhatikan kenyataan ini, penulis memandang perlunya seorang penghafal AlQur'an tak hanya sekedar menghafal saja, tetapi juga harus belajar kitab adab penghafal Al-Qur'an, salah satunya adalah Kitab At- 
Tibyan Fi Adabi Hamalat Al-Qur'an. Pembelajaran kitab At-Tibyan ini fokus mengkaji adab dan akhlak dalam menghafal Al-Qur'an.

Maskanul Huffadz adalah sebuah yayasan sosial yang fokus kepada pendidikan non formal khususnya menghafal Al-Qur'an. Yayasan ini sudah tumbuh dan berkembang dalam penyelenggaraan program tahfidz AlQur'an selama hampir lima tahun. Dalam proses pembelajaran Quran, para santri dibekali dengan ilmu adab dan akhlak yang terkandung dalam kitab At-Tibyan, sehingga mereka tidak hanya kompeten secara hafalan, tapi juga mulia secara adab dan akhlak.

Mempelajari kitab At-Tibyan untuk sebagian orang mungkin adalah hal yang sulit dan membosankan, karena buku asli kitab ini ditulis dalam Bahasa Arab. Salah satu keunggulan Teknologi Pendidikan adalah dapat memfasilitasi peserta didik dalam mempelajari sesuatu secara mudah, efisien, dan efektif. Untuk itu perlu dilakukan pengembangan sistem pembelajaran kitab AtTibyan yang mudah dimengerti oleh santri, dan terukur secara hasil belajarnya. Rumusan masalah penelitian ini adalah (a) bagaimana pengembangan sistem pembelajaran kitab At-Tibyan yang efisien dan efektif? bahan pembelajaran yang bagaimana yang dapat menunjang pembelajaran kitab AtTibyan, dan (c) bagaimana pedoman penilaian keberhasilan peserta didik dalam mempelajari kitab At-Tibyan?

\section{KAJIAN LITERATUR \\ - MODEL PEMBELAJARAN}

Model pembelajaran adalah kerangka tahapan sistematis dalam mengatur pengalaman belajar guna mencapai tujuan belajar, serta berfungsi sebagai panduan bagi guru untuk mengimplementasikan kegiatan pembelajaran. (Huda, 2011). Model pembelajaran harus dimengerti guru untuk dapat melakukan proses pembelajaran dengan baik dalam meningkatkan hasil belajar yang baik pula. Tentunya masingmasing guru mempunyai beragam strategi untuk membantu peserta didik mempelajari sebuah pembelajaran dari guru itu sendiri.

Membicarakan model pembelajaran berarti membicarakan pula desain pembelajaran. Hasil dari desain pembelajaran adalah tersedianya suatu sistem pembelajaran. (Suradika et al., 2020) menjelaskan bahwa yang dimaksud sistem pembelajaran adalah " $a$ collection of elements that interact and are interdependent with each other in an effort to facilitate learning to achieve learning objectives" (Seperangkat unsur-unsur yang saling berinteraksi dan saling bergantung satu sama lain dalam upaya memfasilitasi pembelajaran untuk tercapainya tujuan pembelajaran)

Dalam desain pembelajaran dikenal beberapa model yang dikemukakan oleh para ahli. Secara umum, model desain pembelajaran dapat diklasifikasikan ke dalam model berorientasi kelas, model berorientasi sistem, model berorientasi produk, model prosedural dan model melingkar. Model berorientasi kelas biasanya ditujukan untuk mendesain pembelajaran level mikro (kelas) yang hanya dilakukan setiap dua jam pelajaran atau lebih. Contohnya adalah model ASSURE.

Model pembelajaran ASSURE merupakan salah satu model yang dapat menuntun pembelajar secara sistematis untuk 
merencanakan proses pembelajaran secara efektif. Model ini diperkenalkan oleh Heinich, Molanda, dan Russell pada tahun 1989, khususnya pada kegiatan pembelajaran yang menggunakan media dan teknologi. Desain pembelajaran ASSURE merupakan salah satu desain pembelajaran sederhana, mudah dipelajari serta memanfaatkan media dan teknologi. Model ini dikembangkan untuk menciptakan aktivitas pembelajaran yang efektif dan efisien, khususnya pada kegiatan pembelajaran yang menggunakan media dan teknologi (Pribadi, 2009).

Model desain pembelajaran ASSURE ini adalah suatu model desain pembelajaran yang merupakan sebuah formulasi untuk kegiatan belajar mengajar (KBM) yang berorientasi kelas. Model ASSURE merupakan jembatan antara peserta didik, materi, dan media. Model ini bersifat praktis dan mudah diimplementasikan dalam mendesain aktivitas pembelajaran. Dalam menganalisis karakteristik siswa sangat memudahkan untuk menentukan metode, media dan bahan pembelajaran yang akan digunakan, sehingga dapat menciptakan aktivitas pembelajaran yang efektif, efisien dan menarik (Achmadi et al., 2014).

Setiap kegiatan belajar mengajar yang efektif tentu karena perencanaan yang baik. Kegiatan pembelajaran akan maju setelah melalui beberapa tahapan. (Gagné et al., 1992) mengartikan tahapan itu adalah saat proses pembelajaran terjadi. Hasil penelitian Gagne mengungkapkan bahwa desain materi belajar dimulai dengan membangkitkan rasa keingintahuan siswa pada materi-materi yang baru. Mendorong serta melatih siswa dengan umpan balik, menilai pemahaman siswa, dan mendorong siswa untuk melanjutkan aktivitas yang ingin diketahuinya.

Menurut (Heinich et al., 2002) model ASSURE ini terdiri atas enam langkah kegiatan yaitu: Analyze Learners, States Objectives, Select Methods, Media, and Material, Utilize Media and materials, Require Learner Participation Evaluate and Revise.

1. Analisis Pelajar. Menurut (Heinich et al., 2002) jika sebuah media pembelajaran akan digunakan secara baik dan disesuaikan dengan ciri-ciri oelajar, isi dari pelajaran yang akan dibuatkan medianya, media dan bahan pelajaran itu sendiri. Lebih lanjut Heinich, 2005 menyatakan sukar untuk menganalisis semua ciri pelajar yang ada, namun ada tiga hal penting dapat dilakukan untuk mengenal pelajar sesuai. berdasarkan ciri-ciri umum, keterampilan awal khusus dan gaya belajar.

2. Menyatakan Tujuan. Menyatakan tujuan adalah tahapan ketika menentukan tujuan pembelajaran baik berdasarkan buku atau kurikulum. Tujuan pembelajaran akan menginformasikan apakah yang sudah dipelajari anak dari pengajaran yang dijalankan. Menyatakan tujuan harus difokuskan kepada pengetahuan, kemahiran, dan sikap yang baru untuk dipelajari 
3. Pemilihan Metode, media dan bahan (Heinich et al., 2002) menyatakan ada tiga hal penting dalam pemilihan metode, bahan dan media yaitu menentukan metode yang sesuai dengan tugas pembelajaran, dilanjutkan dengan memilih media yang sesuai untuk melaksanakan media yang dipilih, dan langkah terakhir adalah memilih dan atau mendesain media yang telah ditentukan.

4. Penggunaan Media dan bahan Menurut (Heinich et al., 2002) terdapat lima langkah bagi penggunaan media yang baik yaitu, preview bahan, sedia bahan, sediakan persekitaran, pelajar dan pengalaman pembelajaran.

5. Partisipasi Pelajar di dalam kelas Sebelum pelajar dinilai secara formal, pelajar perlu dilibatkan dalam aktivitas pembelajaran seperti memecahkan masalah, simulasi, kuis atau presentasi.

6. Penilaian dan Revisi Sebuah media pembelajaran yang telah siap perlu dinilai untuk menguji keberkesanan dan impak pembelajaran. Penilaian yang dimaksud melibatkan beberapa aspek diantaranya menilai pencapaian pelajar, pembelajaran yang dihasilkan, memilih metode dan media, kualitas media, penggunaan guru dan penggunaan pelajar.

Maka berdasarkan uraian diatas, dapat disimpulkan bahwa penerapan model pembelajaran ASSURE ini cocok untuk pembelajaran kitab At-Tibyan.

\section{- HAKIKAT PEMBELAJARAN} KITAB AT-TIBYAN

Sebagaimana yang sudah disebutkan di atas, pembelajaran kitab At-Tibyan ini tentunya fokus kepada kajian adab dan akhlak para penghafal Al-Qur'an. Adab dan akhlak atau etika para penghafal Al-Qur'an antara lain (1) seorang penghafal Al-Qur'an harus memiliki akhlak dan perangai yang baik. Dalam hal ini, penghafal Al-Qur'an dapat meniru Akhlak Rasulullah SAW dengan suri teladan yang baik bagi seluruh umatnya, (2) seorang penghafal Al-Qur'an harus meninggalkan segala sesuatu yang dilarang oleh Allah Swt., (3) seorang penghafal Al-Qur'an harus menghindari pekerjaan yang rendah ,yang artinya bekerja dari sumber yang syubhat bahkan tidak halal/haram, (4) seorang penghafal AlQur'an harus memiliki jiwa yang mulia, artinya jiwa mulia ini adalah jiwa yang bersih, yang selalu mempunyai prasangka baik terhadap penciptaan makhluknya, (5) seorang penghafal Al-Qur'an lebih tinggi derajatnya dari penguasa yang sombong .dalam hal ini, pantang bagi seorang penghafal Al-Qur'an merendahkan diri didepan penguasa yang sombong, (6) seorang penghafal Al-Qur'an harus tawadu terhadap orang-orang yang saleh, artinya para penghafal Al-Qur'an harus santun terhadap semua orang khususon kepada orang-orang yang saleh dan yang mencintai anak yatim serta orang miskin, (7) seorang penghafal Al- 
Qur'an harus khusyuk jiwanya, tenang bahkan berwibawa, artinya dia harus tenang dalam pembawaannya dan menjadi sosok yang sabar dalam menjaga Al-Qur'an, (8) seorang penghafal Al-Qur'an jangan menjadikan Al-Qur'an sebagai sumber penghasilan atau sandaran hidupnya, artinya seorang penghafal Al-Qur'an tidak berorientasi pada hal yang sifatnya duniawi dan menjadikan Al-Qur'an sebagai sarana dalam mencapainya, dan (9) seorang penghafal Al-Qur'an harus selalu mengulang hafalannya. Karena Al-Qur'an adalah amanat yang sangat agung terkhusus bagi para penghafal Al-Qur'an. Selayaknya kita harus merasa malu ketika tidak bisa menjaga hafalannya.

\section{METODE PENELITIAN}

Dalam sebuah penelitian yang membahas rancangan/pengembangan pembelajaran, pilihan metode yang sesuai adalah metode $R$ and $D$ (Research and Development). Metode R\&D merupakan metode penelitian yang digunakan untuk meneliti sehingga menghasilkan produk baru dan selanjutnya menguji keefektifan produk tersebut. Oleh karena itu, laporan penelitian yang dibuat selalu dilampiri dengan produk yang dihasilkan berikut spesifikasi dan penjelasannya. Metode $R$ and $D$ memadukan dua pendekatan penelitian: kuantitatif dan kualitatif (mixed methode) yang menekankan pada proses dan hasil (Suradika \& Wicaksono, 2019)

Dalam proses penelitian ini, penulis akan membuat beberapa produk pembelajaran kitab At-Tibyan untuk dipakai dalam proses pembelajaran bersama santri, lalu akan dilihat hasil atau keefektifan dari produk tersebut seiring dengan penilaian hasil evaluasi pembelajaran santri.

\section{PEMBAHASAN \\ - ANALISIS PELAJAR.}

Menganalisis para santri yang belajar di Maskanul Huffadz, mereka adalah para santri berprestasi yang sudah melalui tahap seleksi yang ketat, sehingga tingkat pemahaman mereka akan sebuah materi yang disampaikan cukup baik dan cukup cepat. Ini membuat proses transfer materi bisa berjalan dengan baik.

Tingkat pemahaman yang baik dan kecerdasan yang mumpuni ini tidak hanya dibutuhkan para santri dalam proses menghafAl-Qur'an, tapi tentu juga akan sangat berpengaruh dalam proses penerapan adab. Maka sebagai pengajar, tentu selain ingin hafalan baik yang dimiliki oleh para santri, juga dilengkapi dengan adab baik yang diterapkan para santri pula.

\section{- MENYATAKAN TUJUAN.}

Sebagaimana yang sudah diuraikan pada bagian sebelumnya, maka tujuan dari pembelajaran ini adalah untuk membentuk adab dan akhlak terbaik dari para penghafAlQur'an. Secara eksplisit Tujuan Instruksional Umumnya dirumuskan sebagai berikut : "Setelah mengikuti pembelajaran kitab AtTibyan, santri akan dapat mengimplementasikan adab dan akhlak penghafal Al-Qur'an", secara terinci diuraikan menjadi beberapa Tujuan Instruksional Khusus sebagai berikut (a) setelah mengikuti pembelajaran dengan topik akhlak dan akhlak penghafal Al-Qur'an dalam kitab At-Tibyan, santri dapat menjelaskan Sembilan adab dan akhlak sebagai penghafal Al-Qur'an, (b) setelah 
mengikuti pembelajaran dengan topik bahasan sikap terhadap adab dan akhlak penghafal Al-Qur'an, santri memiliki sikap positif terhadap adab dan akhlak penghafal Al-Qur'an, dan (c) setelah mengikuti pembelajaran tentang keteladanan adab dan akhlak penghafal Al-Qur'an, santri dapat mengimplementasikan adab dan akhlak penghafal Al-Qur'an dalam kehidupan sehari-hari.

- PEMILIHAN METODE, MEDIA DAN BAHAN

Dalam rancangan pembelajaran ini, direncanakan metode dan media yang digunakan akan sangat variatif. Mulai dari metode ceramah, diskusi, bahkan kerja kelompok.

Dalam metode ceramah, pengajar menjelaskan secara langsung materi ajar yang ingin disampaikan. Pengajar membagi setiap bab dalam 1-3 kali pertemuan (sesuai dengan bahasan setiap bab), sehingga pengajar bisa menyampaikan materi dengan jelas. Lalu dalam metode diskusi, pengajar membuka sesi tanya jawab dimana setiap santri bebas menanyakan hal-hal terkait materi ajar dan membuka kesempatan berbagi pengalaman.

Metode kerja kelompok juga diterapkan dalam proses pembelajaran kitab At-Tibyan, dimana pengajar membagi santri kedalam beberapa kelompok lalu memberikan masing-masing kelompok tema ajar untuk dijelaskan kepada santri

\section{- PENGGUNAAN MEDIA DAN BAHAN}

Media juga berperan sangat penting, dimana jika suatu materi disampaikan dengan media seperti Power Point atau video-video, materi pembelajaran lebih jelas dan lebih mudah untuk dipahami oleh santri.

Power point digunakan oleh pengajar dalam proses mengajar kitab At-Tibyan untuk memudahkan penjelasan materi buku ini dalam poin-poin, sebagaimana yang kita ketahui Bersama bahwa kitab At-Tibyan ini berisi paragraf-paragraf penjelas yang cukup Panjang, sehingga jika disampaikan dalam bentuk power point, maka santri lebih mudah memahami isi dari kitab ini. Serta sebagai pendukung, biasanya pengajar juga menyertakan video-video inspiratif dan motivatif agar abad-adab yang disampaikan lebih tergambar dengan jelas.

\section{- PARTISIPASI PELAJAR DI} DALAM KELAS.

Para santri juga berperan aktif dalam proses pembelajaran. Mereka mengikuti pembelajaran kitab At-Tibyan dengan sangat antusias

Pembelajaran biasanya dilakukan dalam 1 jam (60 menit), yang dibagi kedalam 2 sesi; sesi pertama selama 45 menit adalah penjelasan materi dari pengajar, dan sesi kedua dalam 15 menit adalah sesi tanya jawab bagi pelajar/santri di dalam kelas.

\section{- PENILAIAN DAN REVISI.}

Pada masa akhir pembelajaran tentu ada evaluasi. Evaluasi yang penulis lakukan adalah dengan membentuk kelompok dari para santri, lalu mereka akan menjelaskan materi bab yang sudah dibagi. Selain itu, evaluasi juga dilakukan dengan mewawancara langsung apa-apa saja yang didapatkan selama proses belajar kitab AtTibyan serta apa efek baik dari pembelajaran kitab ini. 


\section{PENUTUP}

Berdasarkan uraian yang telah dikemukakan pada bagian sebelumnya, dapat disimpulkan beberapa hal sebagai berikut:

1. Rancangan pembelajaran kitab AtTibyan yang efisien dan efektif dapat disusun dengan menggunakan model ASSURE. Rancangan pembelajaran ini terdiri dari enam tahapan perancangan, dimulai dari melakukan analisis terhadap para santri sampai mengevaluasi hasil dari pembelajaran.

2. Bahan pembelajaran berupa (a) silabus pembelajaran dalam satu semester, (b) bahan belajar dalam bentuk power point dan video edukatif yang menunjang setiap bab pembelajaran sesuai dengan tujuan pembelajaran kitab AtTibyan, dipandang layak untuk digunakan dalam proses pembelajaran.

3. Pedoman penilaian keberhasilan peserta didik selama program belajar berlangsung dipandang cukup baik untuk mengukur keberhasilan pembelajaran kitab At-Tibyan.

\section{REFERENSI}

Achmadi, H., Suharno, \& Suryani, N. (2014). Penerapan Model Assure Dengan Menggunakan Media Power Point
Dalam Pembelajaran Bahasa Inggris Sebagai Usaha Peningkatan Motivasi Dan Prestasi Belajar Siswa Kelas X MAN Sukoharjo Tahun Pelajaran 2012/2013. Jurnal Teknologi Pendidikan Dan Pembelajaran, 2(1), 35-48.

Gagné, R. M., Briggs, L. G., Briggs, L. J., \& Wager, W. W. (1992). Principles of Instructional Design. Harcourt Brace Jovanovich College Publishers. https://books.google.co.id/books?id= LH3UAAAAMAAJ

Heinich, R., Molenda, M., Smaldino, S. E., \& Russell, J. D. (2002). Instructional Media and Technologies for Learning. Merrill/Prentice Hall.

Huda, M. (2011). Cooperative Learning (Vol. 113). Pustaka Pelajar.

Pribadi, R. B. A. (2009). DESAIN SISTEM PEMBELAJARAN. PT. Dian Rakyat.

Suradika, A., \& Wicaksono, D. (2019). Metodologi Penelitian. UM Jakarta Press.

Suradika, A., Winata, W., Wicaksono, D., Hadi, M. S., \& Rifqiyati. (2020). The Influence of Instructional Materials and Educational Background on the Learning Outcomes of Islamic Education. Solid State Technology, 63(6), 1027-1043. http://solidstatetechnology.us/index.p hp/JSST/article/view/2185 